\title{
Successful resection of a granulocyte colony-stimulating factor-producing carcinoma of the pancreas: A case report
}

\author{
TAKAYUKI AKASAKI $^{1}$, TAKAHIRO EINAMA ${ }^{1}$, KEITA TASHIRO $^{1}$, HIROMI NAGATA $^{1}$, KENJI YAMAZAKI $^{1}$, \\ MAKOTO NISHIKAWA ${ }^{1}$, MAYUMI HOSHIKAWA ${ }^{1}$, AKIFUMI KIMURA ${ }^{1}$, TAKUJI NORO ${ }^{1}$, SHO OGATA ${ }^{2}$, \\ SUEFUMI AOSASA ${ }^{1}$, YOSHIKI KAJIWARA ${ }^{1}$, EIJI SHINTO ${ }^{1}$, YOSHIHISA YAGUCHI ${ }^{1}$, SHUICHI HIRAKI ${ }^{1}$, \\ HIRONORI TSUJIMOTO $^{1}$, KAZUO HASE ${ }^{1}$, HIDEKI UENO ${ }^{1}$ and JUNJI YAMAMOTO ${ }^{1}$
}

Departments of ${ }^{1}$ Surgery and ${ }^{2}$ Pathology, National Defense Medical College, Tokorozawa, Saitama 359-8513, Japan

Received November 29, 2018; Accepted July 3, 2019

DOI: $10.3892 / \mathrm{mco} .2019 .1902$

\begin{abstract}
Granulocyte colony-stimulating factor (G-CSF) is a naturally occurring glycoprotein that stimulates the proliferation of precursor cells in the bone marrow and their maturation into fully differentiated neutrophils. G-CSF-producing cancers rarely occur in the digestive system, particularly the pancreas. Herein we report the rare case of a G-CSF-producing pancreatic carcinoma associated with severe anemia due to bleeding in the duodenum, which was successfully treated with surgery. A 79 year-old man presented with epigastralgia and anemia at our institution. Esophagogastroduodenoscopy revealed a duodenal tumor, which was diagnosed as a poorly differentiated adenocarcinoma. To control breeding, subtotal stomach-preserving pancreaticoduodenectomy was performed. The excised tumor measured 86x55x54 mm. It was primarily located in the pancreas and compressed the pancreatic parenchyma and main bile duct. It comprised poorly differentiated adenocarcinoma, and prominent neutrophil infiltration was noted around the tumor. Immunohistochemical examination revelaed that the tumor was positive for G-CSF expression. Based on these results, a final diagnosis of G-CSF-producing primary pancreatic cancer was made. At 18 months following surgery, the patient was alive without recurrence.
\end{abstract}

\section{Introduction}

Granulocyte colony-stimulating factor (G-CSF) is a naturally occurring glycoprotein that stimulates the proliferation of precursor cells in the bone marrow and their maturation into fully differentiated neutrophils (1). The lung is the most

Correspondence to: Dr Takahiro Einama, Department of Surgery, National Defense Medical College, 3-2 Namiki, Tokorozawa, Saitama 359-8513, Japan

E-mail: titiuehahaue@hotmail.com

Key words: granulocyte colony-stimulating factor, granulocyte colony-stimulating factor-producing cancer, pancreatic cancer, pancreaticoduodenectomy, adenocarcinoma common site of G-CSF-producing cancers. In the digestive system, particularly the pancreas, G-CSF-producing cancers are very rare, and there is no standardized treatment for these cancers. The prognosis of patients with these cancers has been reported to be very poor (2). Herein, we report a rare case of a G-CSF-producing pancreatic carcinoma associated with severe anemia due to bleeding in the duodenum, which was successfully treated with surgery.

\section{Case presentation}

A 79-year-old man presented to another hospital with slight fever. Contrast-enhanced computed tomography (CT) revealed a $40-\mathrm{mm}$ tumor in the right lung field. Lung biopsy was performed, and he was diagnosed with lung cancer. After a discussion regarding the treatment options, he didn't want invasive treatment. He decided to undergo radiotherapy (70 Gy) for 3 months, and the tumor size decreased to $15 \mathrm{~mm}$ (Fig. 1). After 1 month, he underwent radiotherapy and experienced epigastralgia. Laboratory tests showed abnormal values for white blood cell count $(12,700 / \mu 1$; reference range, 3,500-9,800/ $\mu 1)$, neutrophil percentage (83.1\%; reference range, $44-74 \%)$, hemoglobin level $(6.3 \mathrm{~g} / \mathrm{dl}$; reference range, 13.5-17.5 g/dl), and C-reactive protein (CRP) level $(14.2 \mathrm{mg} / \mathrm{dl}$; reference range, $0-0.6 \mathrm{~g} / \mathrm{dl})$. He did not have any signs of infection. Tumor maker levels were as follows: Carcinoembryonic antigen, $5.9 \mathrm{ng} / \mathrm{dl}$ (upper reference limit, $5.0 \mathrm{ng} / \mathrm{dl}$ ); s-pancreas-1 cancer antigen, $41.0 \mathrm{U} / \mathrm{ml}$ (upper reference limit, $30.0 \mathrm{U} / \mathrm{ml}$ ); squamous cell carcinoma antigen, $5.4 \mathrm{ng} / \mathrm{ml}$ (upper reference limit, $1.5 \mathrm{ng} / \mathrm{ml}$ ); and carbohydrate antigen 19-9, $297.3 \mathrm{IU} / \mathrm{ml}$ (upper reference limit, $37.0 \mathrm{IU} / \mathrm{ml}$ ). Abdominal CT revealed a $55-\mathrm{mm}$ hypervascular tumor at the second part of the duodenum (Fig. 2). Upper endoscopy revealed that the tumor was the lumens of the first and second parts of the duodenum, mainly at the posterior wall. A clot was noted on the tumor, but no ulcer was present (Fig. 3). Pathological examination identified a poorly differentiated adenocarcinoma. Based on these results, we made differential diagnoses of primary duodenum carcinoma and metastatic duodenal cancer associated with the right lung cancer. We performed subtotal stomach-preserving pancreaticoduodenectomy to control bleeding. 


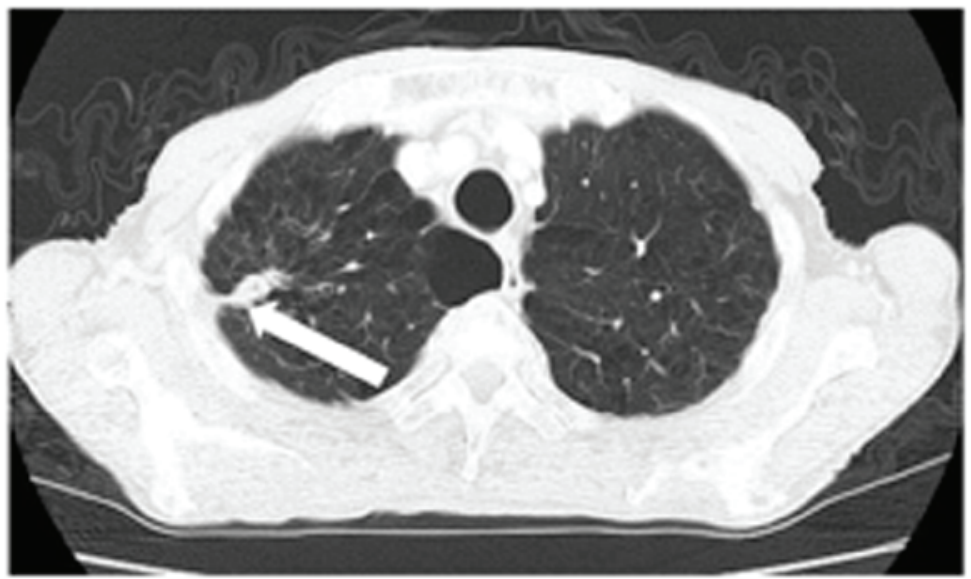

Figure 1. Chest CT shows a tumor in the right lung S1 area. White arrow points the tumor in the right lung. CT, computed tomography.

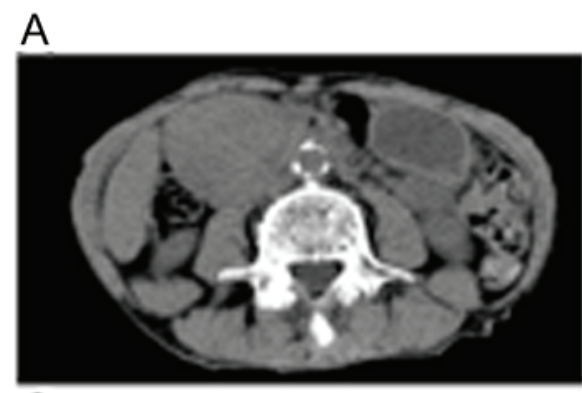

C

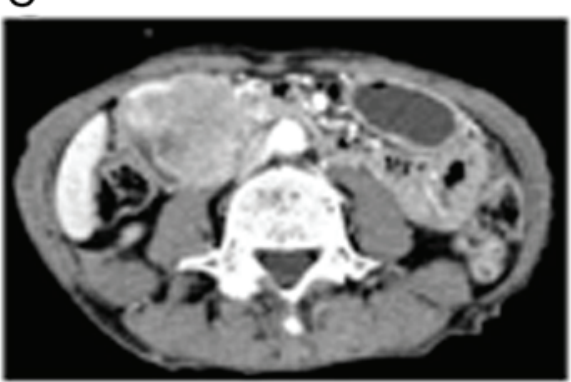

B

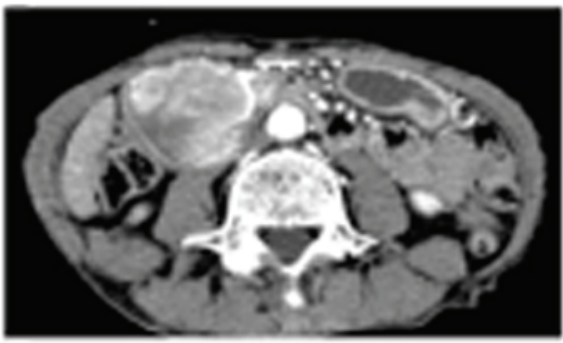

$\mathrm{D}$

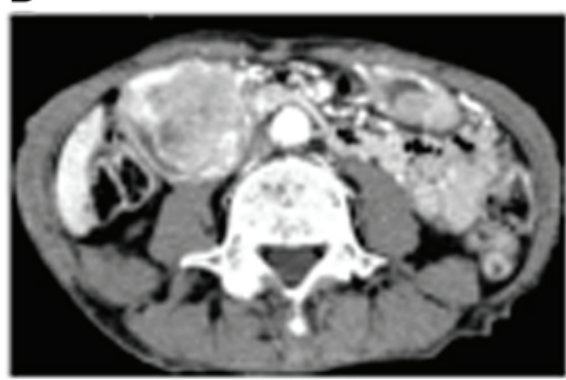

Figure 2. Abdominal CT shows a 55-mm tumor in the second part of the duodenum with high vascularity. (A) Plain; (B) arterial phase; (C) portal phase; (D) equilibrium phase. CT, computed tomography.

The excised tumor measured $86 \times 55 \times 54 \mathrm{~mm}$. The tumor mainly occupied the pancreatic head and compressed the pancreatic parenchyma and common bile duct. It comprised a poorly differentiated adenocarcinoma, and prominent neutrophil infiltration was noted around the tumor. In addition, we identified metastasis in 1 of 13 lymph nodes and lymphatic and venous invasion. The final pathological diagnosis was T3N1aM0, Stage IIB. On immunohistochemical examination, which involves the process of selectively identifying antigens in cells of a tissue section by exploiting the principle of antibodies binding specifically to antigens in biological tissues, the tumor was positive for G-CSF and negative for thyroid transcription factor 1 (TTF-1). Evaluations of a lung biopsy specimen indicated an adenocarcinoma with clear cells and TTF-1 positivity (Fig. 4). Based on these results, we made a final diagnosis of G-CSF-producing primary pancreatic cancer.

The CRP level decreased from $14.2 \mathrm{mg} / \mathrm{dl}$ on the day before the surgery to $0.3 \mathrm{mg} / \mathrm{dl}$ on postoperative day (POD) 13 .

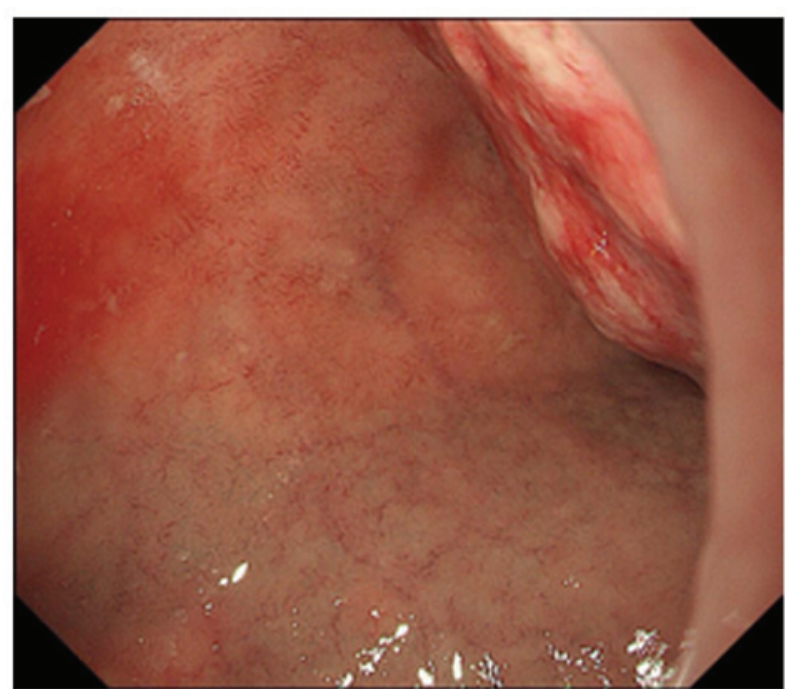

Figure 3. Esophagogastroduodenoscopy shows a bleeding duodenal tumor. 
Table I. Reported cases of granulocyte colony-stimulating factor-producing pancreatic cancer.

\begin{tabular}{|c|c|c|c|c|c|c|c|c|c|}
\hline Author, year & Age & Sex & Symptoms & Location & $\begin{array}{c}\text { Pathological } \\
\text { diagnosis }\end{array}$ & Operation & Chemo & Prognosis & (Refs.) \\
\hline $\begin{array}{l}\text { Ohwada et al, } \\
1989\end{array}$ & 83 & M & Back pain & Body & $\mathrm{scc}$ & No & 5FU, THP, MMC & $\begin{array}{c}\text { Dead } \\
\text { (4 months) }\end{array}$ & (4) \\
\hline $\begin{array}{l}\text { Kawakami et al, } \\
2007\end{array}$ & 56 & M & Back pain & Body and tail & por & No & GEM, S-1 & $\begin{array}{c}\text { Dead } \\
\text { (4 months) }\end{array}$ & (5) \\
\hline $\begin{array}{l}\text { Nakajima et al, } \\
2008\end{array}$ & 63 & M & Weight loss & - & ana & No & - & $\begin{array}{c}\text { Dead } \\
\text { (11 days) }\end{array}$ & (2) \\
\hline $\begin{array}{l}\text { Murata et al, } \\
2009\end{array}$ & 59 & M & Epigastralgia & Body and tail & ana & Yes & $\begin{array}{c}\text { GEM+ } \\
\text { Radiation }\end{array}$ & $\begin{array}{c}\text { Dead } \\
\text { (8 months) }\end{array}$ & (6) \\
\hline $\begin{array}{l}\text { Ikeda et al, } \\
2013\end{array}$ & 70 & $\mathrm{~F}$ & Weight loss & Body and tail & ana & No & S-1 & $\begin{array}{c}\text { Dead } \\
\text { (88 days) }\end{array}$ & (7) \\
\hline $\begin{array}{l}\text { Kitade et al, } \\
2015\end{array}$ & 68 & M & Weight loss, Fever & Tail & ana & Yes & S-1 & $\begin{array}{c}\text { Dead } \\
\text { (83 days) }\end{array}$ & (8) \\
\hline $\begin{array}{l}\text { Hayashi et al, } \\
2016\end{array}$ & 50 & M & Fever & Body & ana & No & S-1, GEM & $\begin{array}{c}\text { Dead } \\
\text { (123 days) }\end{array}$ & (9) \\
\hline $\begin{array}{l}\text { Vinzens et al, } \\
2017\end{array}$ & 67 & M & Abdominal pain & Tail & ana & Yes & $\begin{array}{c}\text { Oxa, CPT-11, } \\
\text { 5-FU }\end{array}$ & $\begin{array}{c}\text { Dead } \\
\text { (34 days) }\end{array}$ & (10) \\
\hline $\begin{array}{l}\text { Seki et al, } \\
2018\end{array}$ & 65 & M & Not described & Head & ana & Yes & - & $\begin{array}{c}\text { Dead } \\
\text { (58 days) }\end{array}$ & (11) \\
\hline Present study & 79 & M & Fever & Head & por & Yes & S-1 & $\begin{array}{c}\text { Alive } \\
\text { without } \\
\text { recurrence }\end{array}$ & \\
\hline
\end{tabular}

aPrognosis after diagnosis. scc, squamous cell carcinoma; por, poorly differentiated adenocarcinoma; ana, anaplastic carcinoma; THP, pirarubicin hydrochloride; GEM, gemcitabine; Oxa, oxaliplatin; 5-FU, 5-fluorouracil; MMC, mitomycinC; CPT-11, irinotecan.

A

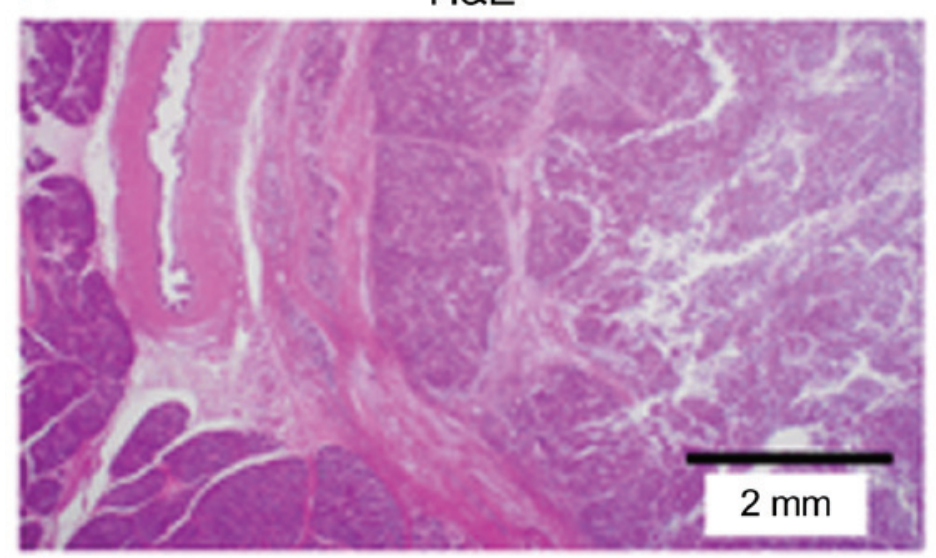

B GCSF

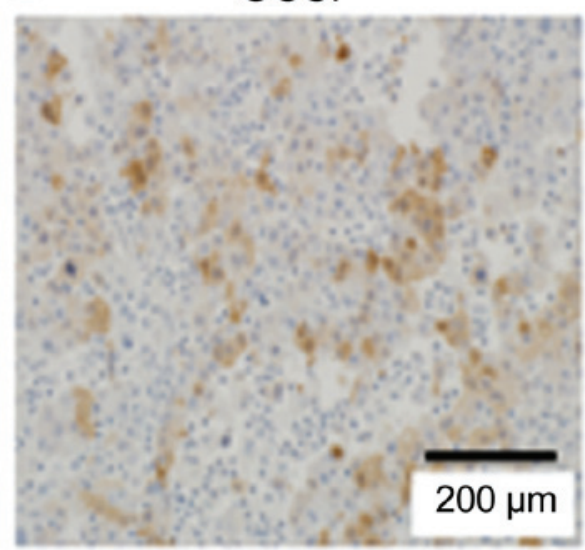

Figure 4. Microscopic finding. (A) The tumor is mainly present in the pancreas and compresses the bile duct and pancreatic parenchyma. It comprised a poorly differentiated adenocarcinoma, and prominent neutrophil infiltration is noted around the tumor. (B) Immunohistochemical analysis of the resected specimen shows G-CSF expression. G-CSF, granulocyte colony-stimulating factor.

Although he experienced delayed gastric emptying after the surgery, he was discharged on POD 38 (Fig. 5). He was administered S-1 twice a day as adjuvant chemotherapy for 2 weeks but suffered from adverse drug reaction. We stopped administrating. At 18 months after surgery, he is currently alive without recurrence including lung cancer.

\section{Discussion}

A G-CSF-producing tumor in the pancreas is very rare. The first case of G-CSF-producing lung cancer was reported by Asano in 1977, and many reports on such tumors have been subsequently published (3). Usually, patients with 
A

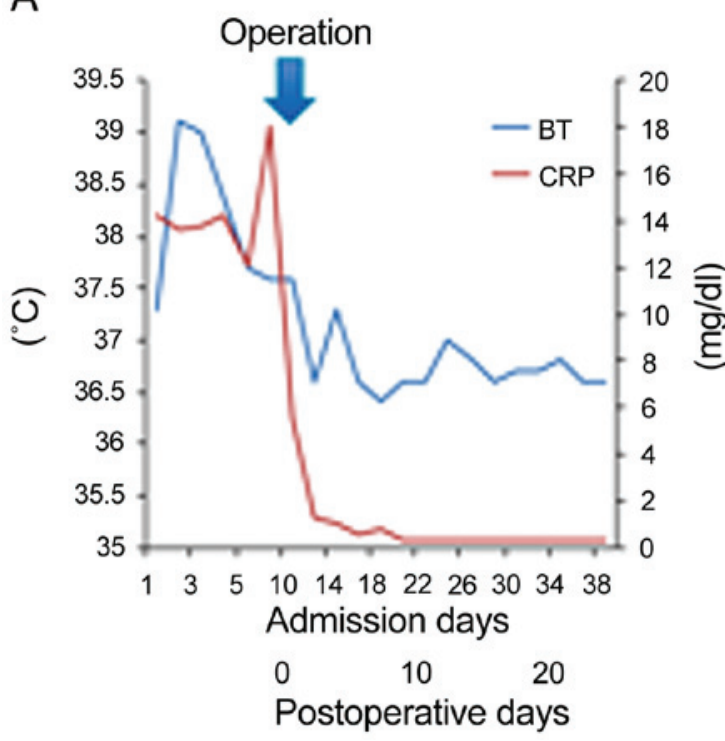

B

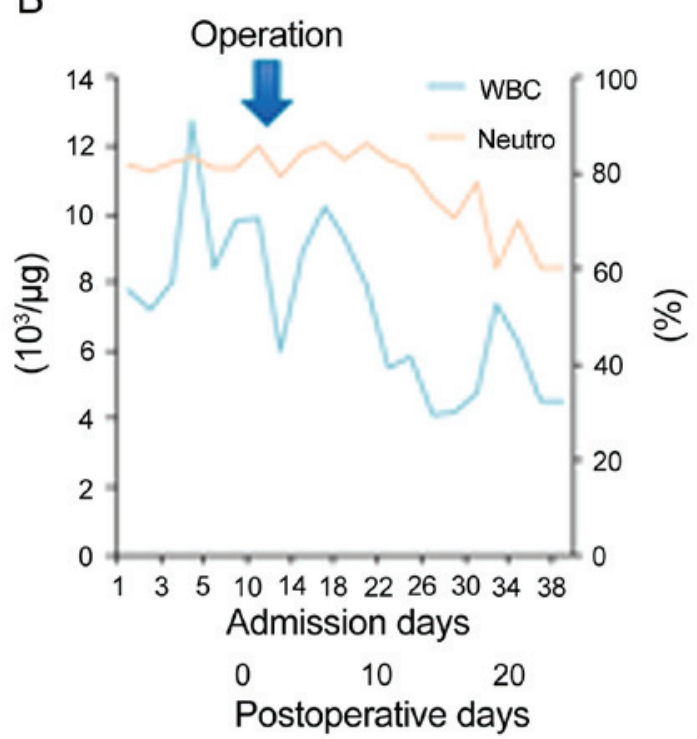

Figure 5. (A) The CRP level shows a decrease from $14.2 \mathrm{mg} / \mathrm{dl}$ on the day before the operation to $0.3 \mathrm{mg} / \mathrm{dl}$ on post operation. (B) The white blood cell count level and neutrophil percentage show a decrease from $12,700 / \mu 1$, and $83.1 \%$ on the day before the operation to $4,500 / \mu 1$, and $60 \%$ on post operation. CRP, C-reactive protein; WBC, white blood cell; BT, body temperature.

G-CSF-producing tumors have fever and leukocyte elevation without having an infection because of G-CSF elevation in the blood. The diagnostic criteria for G-CSF-producing tumors are as follows: i) Extreme leukocytosis; ii) elevated G-CSF activity; iii) decreased white blood cell count after tumor resection, and iv) detection of G-CSF production in the tumor (3). In the present study, the patient met three of aforementioned diagnostic criteria.

We searched PubMed using the terms 'granulocyte colony-stimulating factor' and 'pancreatic cancer' and identified nine reported cases of G-CSF-producing pancreatic cancers during the period of 1989-2018 (Table I). The mean age of the 10 patients, including our patient, was 66 years (range, 50-83 years), and there was a predominance in male patients (males, 9; female, 1). Clinically, most patients presented with fever, weight loss, and back pain. Histologically, seven patients had anaplastic carcinomas, two had poorly differentiated adenocarcinomas, and one had a glandular squamous cell carcinoma. Five patients underwent surgery, and eight patients received chemotherapy. Patient survival was very poor, with a median survival period of 132 days after diagnosis. The treatment options reported for this type of cancer include surgical resection, chemotherapy, palliative care, or a combination of these; however, there is no standard treatment. Pathological analyses have identified severe hematogenous metastases in most autopsy reports. Even after curative resection in patients with G-CSF-producing pancreatic cancer, the prognosis is very poor (4). The poor prognosis of these patients might be associated with G-CSF elevation. To evaluate the serum G-CSF we used that the Quantikine Human G-CSF Immunoassay is a 3.5 or $4.5 \mathrm{~h}$ solid phase ELISA designed to measure G-CSF in cell culture supernates, serum, and plasma. It contains E. coli-expressed recombinant human G-CSF and antibodies raised against the protein. It has been shown to accurately quantitate recombinant human G-CSF. A previous study reported a correlation between cancer cell-derived G-CSF and the production of atypical T-cell-suppressive neutrophils in breast cancer and mentioned that G-CSF overexpression increased tumor growth (12).

Our patient had anemia due to bleeding from an erosive lesion in the duodenum associated with pancreatic head cancer invasion. Pancreatic head cancer has a greater tendency to cause symptoms, such as bleeding and obstructive jaundice, than pancreatic body and tail cancers. The tumor location is possibly associated with the detection of this G-CSF-producing cancer without metastasis. Also, the level of white blood cell count was relatively lower than previously reported cases in our case. Early detection may be associated with low white blood cell count. Our patient is alive without an evidence of recurrence 18 months after the surgery. To our knowledge, this is the first report of a patient with G-CSF-producing pancreatic cancer to survive for more than 1 year after treatment. Early detection and complete tumor resection might have improved our patient's survival. Currently, there is no standard treatment for G-CSF-producing pancreatic cancer; however, surgery may be the appropriate first choice for cancers without evidence of remote metastasis.

G-CSF-producing pancreatic cancer is rare, and the prognosis is considered to be very poor. We reported the case of a patient with G-CSF-producing pancreatic cancer who has survived without recurrence for 18 months after curative surgery. Therefore, curative surgery should be considered in patients with localized G-CSF-producing pancreatic cancer.

\section{Acknowledgements}

Not applicable.

\section{Funding}

No funding was received. 


\section{Availability of data and materials}

All data generated or analyzed during the present study are included in this published article.

\section{Authors' contributions}

The supervision of the current study was by YJ; KT, HN, KY, MN, MH, AK, TN, SO, SA, YK, ES, YY, SH, HT, KH, HU interpreted the clinical data and TA and TE wrote, review and/or revised the manuscript. All authors read and approved the manuscript and agree to be accountable for all aspects of the research in ensuring that the accuracy or integrity of any part of the work are appropriately investigated and resolved.

\section{Ethics approval and consent to participate}

Not applicable.

\section{Patient consent for publication}

Written informed consent was obtained from the patient for publication of this case report and any accompanying images.

\section{Competing interests}

No authors report any competing interest.

\section{References}

1. Joshita S, Nakazawa K, Koike S, Kamijo A, Matsubayashi K, Miyabayashi H, Furuta K, Kitano K, Yoshizawa K and Tanaka E: A case of granulocyte-colony stimulating factor-producing hepatocellular carcinoma confirmed by immunohistochemistry. J Korean Med Sci 25: 476-480, 2010.

2. Nakajima A, Takahashi H, Inamori M, Abe Y, Kobayashi N, Kubota K and Yamanaka S: Anaplastic carcinoma of the pancreas producing granulocyte-colony stimulating factor: A case report. J Med Case Rep 2: 391, 2008.

3. Asano S, Urabe A, Okabe T, Sato N and Kondo Y: Demonstration of granulopoietic factor(s) in the plasma of nude mice transplanted with a human lung cancer and in the tumor tissue. Blood 49: 845-852, 1977.
4. Ohwada S, Miyamoto Y, Fujii T, Kuribara T, Teshigawara O, Oyama T, Ishii H, Joshita T and Izuo M: Colony stimulating factor producing carcinoma of the pancreas-a case report. Gan No Rinsho 35: 523-527, 1989 (In Japanese).

5. Kawakami H, Kuwatani M, Fujiya Y, Uebayashi M, Konishi K, Makiyama H, Hashino S, Kubota K, Itoh T and Asaka M: A case of granulocyte-colony stimulating factor producing ductal adenocarcinoma of the pancreas. Nihon Shokakibyo Gakkai ZasshiZasshi 104: 233-238, 2007 (In Japanese).

6. Murata T, Terasaki M, Sakaguchi K, Okubo M, Fukami Y, Nishimae K, Kitayama Y and Hoshi S: A case of anaplastic carcinoma of the pancreas producing granulocyte-colony stimulating factor. Clin J Gastroenterol 2: 109-114, 2009.

7. Ikeda S, Okubo K, Shibahara H, Narita M, Morita K, Takeuchi A Kanazawa H, Ito T, Nishimura D and Katada N: An autopsy of G-CSF-producing anaplastic carcinoma of the pancreas with impaired accumulation on FDG-PET after S-1 chemotherapy. Gan To Kagaku Ryoho 40: 789-792, 2013 (In Japanese).

8. Kitade H, Yanagida H, Yamada M, Satoi S, Yoshioka K, Shikata N and Kon M: Granulocyte-colony stimulating factor producing anaplastic carcinoma of the pancreas treated by distal pancreatectomy and chemotherapy: Report of a case. Surg Case Rep 1: $46,2015$.

9. Hayashi H, Eguchi N, Sumimoto K, Matsumoto K, Azakami T, Sumida T, Tamura T, Sumii M, Uraoka N and Shimamoto F: Autopsy of anaplastic carcinoma of the pancreas producing granulocyte colony-stimulating factor. Nihon Shokakibyo Gakkai ZasshiZasshi 113: 1408-1415, 2016 (In Japanese).

10. Vinzens S, Zindel J, Zweifel M, Rau T Gloor B and Wochner A: Granulocyte colony-stimulating factor producing anaplastic carcinoma of the pancreas: Case report and review of the literature. Anticancer Res 37: 223-228, 2017.

11. Seki H, Yasui N, Shimada A, Matsumoto H and Domoto H: Resection of a granulocyte colony-stimulating factor-producing anaplastic carcinoma of the pancreas, associated with humoral hypercalcemia of malignancy. Gan To Kagaku Ryoho 45: 859-862, 2018 (In Japanese).

12. Cavalloni G, Sarotto I, Pignochino Y, Gammaitoni L, Migliardi G, Sgro L, Piacibello W, Risio M, Aglietta M and Leone F: Granulocyte-colony stimulating factor upregulates ErbB2 expression on breast cancer cell lines and converts primary resistance to trastuzumab. Anticancer Drugs 19: 689-696, 2008.

This work is licensed under a Creative Commons Attribution-NonCommercial-NoDerivatives 4.0 International (CC BY-NC-ND 4.0) License. 